Canadian University Music Review

Canadian University Music Review

Revue de musique des universités canadiennes

\title{
What's the Difference? Reflections on Discourses of Morality, Modernism, and Mosaics in the Study of Music in Canada
}

\section{Beverley Diamond}

Volume 21, numéro 1, 2000

Music Studies in the New Millennium : Perspectives from Canada Les études en musique dans le nouveau millénaire : perspectives canadiennes

URI : https://id.erudit.org/iderudit/1014478ar

DOI : https://doi.org/10.7202/1014478ar

Aller au sommaire du numéro

\section{Éditeur(s)}

Canadian University Music Society / Société de musique des universités canadiennes

\section{ISSN}

0710-0353 (imprimé)

2291-2436 (numérique)

Découvrir la revue

Citer cet article

Diamond, B. (2000). What's the Difference? Reflections on Discourses of Morality, Modernism, and Mosaics in the Study of Music in Canada. Canadian University Music Review / Revue de musique des universités canadiennes, 21(1), 54-75. https://doi.org/10.7202/1014478ar
Résumé de l'article

In different periods of Canadian cultural history, social difference has been articulated by means of discourses of morality, modernism, or mosaics (among others). Each realm of discourse has negotiated various fields of tension between, for instance, the local and the global, tradition and hybridity, or mediated and live performance. These fields of tension are not easily apparent unless we compare discourses relating to different genres of music and sociomusical spheres. The ways in which Canadian ethnomusicology has been complicit with strategies of "managing difference" become clearer with such analysis. Possible post-colonial strategies for empowering voices of difference are also considered in relation to Canadian studies.
All Rights Reserved ( C Canadian University Music Society / Société de musique des universités canadiennes, 2000
Ce document est protégé par la loi sur le droit d'auteur. L'utilisation des services d'Érudit (y compris la reproduction) est assujettie à sa politique d'utilisation que vous pouvez consulter en ligne.

https://apropos.erudit.org/fr/usagers/politique-dutilisation/ 


\title{
WHAT'S THE DIFFERENCE? REFLECTIONS ON DISCOURSES OF MORALITY, MODERNISM, AND MOSAICS IN THE STUDY OF MUSIC IN CANADA
}

\author{
Beverley Diamond
}

Throughout the twentieth century, the multicultural constitution of Canadian society has become more and more central as a trademark of the nation. But we still have much to learn about the roles that folklorists, ethnomusicologists, and musicologists have played in creating, maintaining, or resisting this symbolic currency of ethnocultures. To what extent have we succeeded in avoiding the clichéd language of "diversity" and the reductionism of homogeneous and totalizing accounts of both the ethnocultural communities in which we live and with which we interact? How deeply do we understand how and why communities are congruent (or not) with the social worlds of the different musical genres that we practice/study? At a point where artistic fusion, diasporic culture, transnational media, and the theorization of post-nationhood are central issues in ethnomusicology, to what extent does the place (geographic, historical, experiential) from which we speak or write matter? The answers to such questions will necessarily be interdisciplinary and perhaps even antidisciplinary. ${ }^{1}$ The interdisciplinary will recognize that the study of specific musical genres and different ethnocultural communities in Canada has often been framed by different questions. Recently, caution has been advised with regard to a too easy conflation of issues that may be different in these different genre worlds or communities. ${ }^{2}$ But in my view, it is precisely because "our treatment of Canadian popular music and Canadian concert music are vastly different, not to mention the music of Canada's indigenous peoples," 3 that we need to look across the borders of genre worlds to see factors that shape the interplay of scholarly discourses.

1 Folklorists have taken the lead in this respect. A group defining themselves as the "Undisciplined Women Collective" in the early 1990s have defined important acts of interdisciplinarity as the validation of cultural commentators who are outside academia, the opening up of explorations to a range of perceptions and valences. See Pauline Greenhill and Diane Tye, eds., Undisciplined Women: Tradition and Culture in Canada (Montréal and Kingston: McGill-Queen's University Press, 1997), xi-xii.

2Benita Wolters Fredlund, “'Canada's Lack of National Musical Identity': Thoughts in Response to Karen Pegley's 'Toronto 2000,'” in Discourses in Music 2, no. 1 (2000), an on-line journal located at http://mgsa.sa.utoronto.ca/.

3Fredlund, "'Canada's Lack of National Musical Identity," 1. 
A useful model for examining discourses of multiculturalism has been proposed by a team of Swedish colleagues led by Krister Malm. ${ }^{4}$ Aiming to study the production and organization of cultural diversity in their country, their project seeks to contribute to specific areas of regeneration and vitalization. They view modern musical worlds as "fields of tension," among them homogeneity-diversity, globalization-localization, hybridity-preservation, media-live performance, individualism-collectivities, great traditions-little traditions: "streams or valencies arise between (at least two) conflicting energy sources of various strengths, in various directions, at various levels. The energy sources together with the valencies comprise a field of tension."5

It is the simultaneity of the "fields of tension" idea as well as the metaphor of magnetism that I think could be productive in Canadian studies, particularly if we regard discourses about music as an integral part of the musical practises themselves. In the expansion of the model, Malm explains how various values, metaphors, and social configurations tend to be drawn to one pole or another. Music scholarship frequently offers cases in point. A study of a local musical repertoire, for instance, might overdraw aspects of tradition and authenticity if it failed to recognize a broader dimension of tension that would include the circulation of local musics on recordings or indeed the circulation of knowledge about local musics at such things as academic conferences. Fields of tension are often more apparent if we examine scholarship on different types of music or compare the language of scholars at different historical moments. For example, language used to describe folk music practitioners can sometimes only be explicitly related to class tensions once discourse about other genres of musics and other expressive domains (e.g., dress, literature) is compared.

In this paper, I think through three broad themes that have been frequently mentioned in Canadian music studies, but rarely viewed in relation to the conflicting scholarly positions (energy sources and valencies) that framed their usage. The themes are discourses of morality, modernism, and mosaics. All three have been central to various attempts to articulate how cultural difference might be accommodated within the imaginings of "Canada." While many critics claim that Canadians generally respect cultural difference and vigorously resist the melting pot ideology that we associate with the United States, ${ }^{6}$

\footnotetext{
4 Krister Malm et al., "Music, Media, Multiculture: Project Outline-October 1996," http://www.musakad.se/mmm/projoutline.html (accessed 27 January 2001). Presentations about this project have been made at a conference on "Musicology in Scandinavia" (Turku, Finland, April 2000) by Krister Malm, and at "Toronto 2000: Musical Intersections" (Toronto, Canada, November 2000), by Krister Malm, Owe Ronstrom, and Dan Lundberg, in a paper where the term "fields of tension" had changed to "dimensions of tension." It should be emphasized that the specific evolution of multicultural policies in Canada and Sweden are obviously different; Canada has a longer history and more extensive post-war diversification, as well as a record of more extensive legislation.

5 Malm, "Music, Media, Multiculture," 1.

6Michael Adams, "Canadian and American Social Values," Canada Watch 8, nos. 4-5 (2000): 66-67, 70, for instance, reports on data gathered recently by the Environics Research Group on Canadian and American social values. One of his findings is: "[G]reater willingness on the part of Canadians to accept diversity, as well as Canada's lesser inclination to demand ardent patriotism of its citizens, does not necessarily indicate that Canadians are apathetic about Canada as a nation. Rather, and paradoxically, they feel strongly about their weak attachments to the state, its institutions, and their fellow citizens" (67).
} 
several recent analyses ${ }^{7}$ are vigilant about strategies which have had the effect of "managing" and controlling difference. This paper extends the questions raised in these analyses to music, suggesting that discourses of morality, modernism, and mosaics have often intended respect but effectively played out as strategies of control and management. In the final section of the paper, some suggestions are put forward for shifting these strategies.

I will first look at several inter-related, ideologically marked traces of thinking about these three themes (not the only ones of course) at several historical moments. First, I consider several statements from the late-nineteenth century, a period following confederation when extensive immigration by Chinese railway workers and prairie homesteaders contributed extensively to the diversification of our society. I will then move to a second historical location between the two World Wars when many Euro-Canadians invested considerable energy in nationalist debates; coincidentally, during the same period, legislation barred immigration from Asia and the Middle East. I will reference a third period of scholarship after the 1960s when the highly restrictive immigration policies of the interwar period were finally eliminated and social demography would again shift dramatically. Clearly, I am guilty here of moving rather too quickly over historical locations that need more thorough treatment. Furthermore, the examples I draw upon are mere shards of evidence, albeit ones that are sufficiently consistent to convince me of significant patterns in certain domains of music discourse. The broad historical sweep seems necessary, in my view, to reveal where some problem areas lie, and where detailed research would be fruitful. Additionally, we have been inclined to regard the work of the early periods as neocolonial, less enlightened in its regard for difference than more recent "professional" ethnomusicology. But I will argue that certain issues of diasporic histories, power relations within Canada, and the commercial exploitation of traditional music were widely discussed in the earlier periods. Since these discussions prefigure issues that are very current at the beginning of the twenty-first century, it is useful to compare the different historical locations. I will reinterpret the decades of the 1960s, 1970s, and 1980s - the period of my own professional formation-as a period when English-Canadian ethnomusicology was arguably more complicit (certainly more than we intended) in marginalizing non-white, and non-Anglophone cultures. The specific metaphoric domains that I consider at each historic juncture were all intended to take difference seriously, even though in retrospect we might identify patronizing attitudes that constituted a sort of benevolent racism. Finally, I will consider what some of the challenges are at the turn of the century for a professional praxis that seeks to enable multiple artistic visions and social agendas that are, at times, contested and marginalized. I will also reflect on the ways in which the specific location of working in Canada might inflect that praxis.

7 Several studies that explore the interaction of Canada and the United States in the cultural domain are referenced in notes 8,9 , and 68 . 
In the Swedish model, the fields are proposed as polar opposites and represented as nouns (perhaps implying more fixity and bolder dichotomization than our colleagues intend). Furthermore, the language that is used to express the fields of tension reflects late twentieth-century issues. An application of the model, then, needs to address the following questions: (1) What is the specific discourse of each field of tension at different historical moments and different social locations? What causes the discourse to shift? What insights are occluded or enabled by specific language choice? (2) In an era when we are increasingly wary of binaries, when, in fact, are there actually oppositions and polarities that continue to shape social positions and cultural interpretations? What is going on when oppositions are claimed that are not polarities at all? In specific historical and social locations, whose interests are served by an insistence on pluralism or binarism?

One dimension in which these questions are particularly relevant in Canada is race. I have sometimes argued, along with a number of others, ${ }^{8}$ that race is cast differently in Canada relative to the United States, because we resist the binarism of white and black. We recognize that individuals and groups suffer from something like racist oppression for multiple reasons, including skin colour, but also language, ethnicity, and other dimensions of difference. But I recall one interview with a Western European but non-Anglophone musician from the Prairies, who related how he was told to "speak white" throughout his youth in the 1930s. The anecdote reminds us of the need to explore the circumstances in which the binarism of white and black did govern social relations, perhaps mapped illogically onto language (as in this anecdote), or some other social dimension. The language of "visible minority" (and its implicit opposite, "invisible majority") is a current label that similarly collectivizes and marginalizes very different people within an implicit binary. As Mukherjee has argued, iconic phrases such as "the great white North" may ironically symbolize social exclusions as vividly as the weather. ${ }^{9}$

Another domain in which a field of tension is nuanced in specifically Canadian ways is commerce and music. Although not named in the Swedish list of "fields of tension," commerce is clearly implicated in discussions of the local and global, hybridity and preservation, or media and live performance. But in Canada, commerce is invariably inflected by our association with the US music industry. Many commentators have invested our very nationhood with defiance for the commercial, a defiance often mapped onto anti-Americanism. The discussion below suggests that this is a false dichotomy, and asks whether a multiplicity of fields rather than a binarism is more useful as a framework for research. The "fields of tension" model, as I understand it, encourages such questions. While the general areas identified are fields of tension in every society and every historical period, the language differs,

8 See, for instance, Daley's section on Canada in Ronald Radano and Michael Daley, "Music, Race, Ethnicity, and Nationhood," in the Garland Encyclopedia of World Music, vol. 3, The United States and Canada (New York: Garland, 2000), 63-75.

9 Arun Mukherjee, Oppositional Aesthetics: Readings from a Hyphenated Space (Toronto: TSAR, 1994), 69. 
sometimes extending dualities to multiplicities, and sometimes casting the issues in non-dichotomous fashions. In particular, the approach insists that we view research agendas relationally. It is this relationality that allows us to see how the shifts in metaphoric language may sometimes mask the perpetuation of old issues in new guises.

\section{FOREIGN TO OURSELVES}

The foreigner's friends, aside from bleeding hearts who feel obliged to do good, could only be those who feel foreign to themselves. ${ }^{10}$

To worry or to smile, such is the choice when we are assailed by the strange; our decisions depends on how familiar we are with our own ghosts. ${ }^{11}$

In a short survey I did in 1991 and 1992 for the Association of Canadian Studies on the study of Canadian music in the universities, it was evident that we did indeed have trouble locating "self" and "other" in the curricula of our music schools. At that time, Canadian studies tended to be segregated from North American music studies, and genres were furthermore often defined rather narrowly or taught in separate courses in all but a handful of universities. Furthermore, in a number of cases, Canadian musical traditions were taught in the context of world music courses. ${ }^{12}$ I described this as a narrative in which the Canadian academy continued to view "our" music as the European classical tradition in relation to which Canada was a foreigner. I suggested that "in an age where the dialectic between self and other is intensifying the problems but also suggesting solutions for cultural representation, this rather strange inversion reflects how our colonial heritage lingers on."13 In retrospect, however, I first wondered if this displacing of "our" culture indicated the extent to which all Canadians feel foreign to themselves, as Julia Kristeva describes encounters with the strange. But I conclude it is, in fact, the opposite. The thoroughness with which the European narrative was embodied by many members of the Canadian academy still in the early 1990s indicated an inability to feel foreign to ourselves, to recognize and acknowledge the actual musical practices in our midst in all their bewildering complexity and diversity, to accept that no voice is hegemonic. There were exceptions, of course, particularly in Québec universities, where more courses on local musical practices were paradoxically among the most diverse in musical content. Furthermore, the relative sparsity of music courses that viewed Canada in a continental perspective was slowly

10Julia Kristeva, Strangers to Ourselves, trans. Leon S. Roudiez (New York: Columbia University Press, 1991), 23.

11 Ibid., 191.

12There are more recent analogies in other institutions. Pegley has observed that Newfoundland's Great Big Sea was broadcast on the world music program Cliptrip, on the Canadian video station, MuchMusic, as late as 1995.

13Beverley Diamond, "Canadian Music Studies in University Curricula," Association of Canadian Studies Newsletter 12, no. 3 (1992): 16-18. 
leading to a situation where, in our resistance to US narratives, we were quite unfamiliar with many of our own ghosts. Are we still worrying or smiling?

\section{DISCOURSES OF MORALITY}

[Grandmother Adelia] went in for Culture, which gave her a certain moral authority. It wouldn't now; but people believed, then, that Culture could make you better-a better person. They believed it could uplift you, or the women believed it.

They hadn't yet seen Hitler at the opera house. ${ }^{14}$

Nineteenth-century discourses that reflect the attitude of Atwood's fictional Grandmother Adelia, associating music and moral worth, are not hard to find. ${ }^{15}$ But the fields of tension within which such discourses operated are sometimes unexpected. It is probably not surprising to see morality associated with class. Examples are described by Morey among others: one institution, the choral instruction of the Early Closing Society in Toronto in the 1850s, for instance, was created "for the moral and intellectual uplift of the working classes." 16 Perhaps less obvious are statements that link music's power for moral enhancement to ethnicity and/or race. It is well known that clergy from the Jesuits often described the achievements of Aboriginal persons in learning European music as evidence of moral progress. In a racist pronouncement about the music of Labrador Inuit, for instance, J. E. Hutton attributes their betterment to European music training: "Formerly, in their heathen days, they [the Inuit] could merely howl. Now they revel in Moravian chorales. Both old and young sing correctly in parts; Nain and Okak possess fine brass bands; and some have mastered the viol and cello." 17 Associations between expressive culture (including music, but also literature and visual art), morality, and ethnicity were also commonly made in relation to new immigrant groups on the prairies. Such was the case in a 1877 speech to Manitobans of Icelandic birth, for instance, by Lord Dufferin, who stirred nationalist and moral sentiments simultaneously by arguing: "I trust you will continue to cherish for all time the heart-stirring literature of your nation, and that from generation to generation your little ones will continue to learn in your ancient sagas that industry, energy, fortitude, perseverence and stubborn endurance have ever been the characteristic of the noble Icelandic race." 18 His words were remembered and

14Margaret Atwood, The Blind Assassin (Toronto: McLelland and Stewart, 2001), 59.

15Early twentieth-century examples also abound, for example, in the extensive class analysis offered by Maria Tippett, Making Culture: English-Canadian Institutions and the Arts before the Massey Commission (Toronto: University of Toronto Press, 1990).

16Carl Morey, "Music Education in Nineteenth-Century Toronto," in Taking a Stand: Essays in Honour of John Beckwith, ed. Timothy McGee (Toronto: University of Toronto Press, 1995), 115.

17J. E. Hutton, A History of the Moravian Missions, 1922; cited in Paul Woodford, "We Love the Place, O Lord": A History of the Written Musical Tradition of Newfoundland and Labrador to 1949 (St. John's: Creative Publishers, 1988), 62.

18 Quoted in W. Kristjanson, "Icelandic Settlers in Canada," Icelandic Canadian 1, no. 3 (March 1943): 18. The pattern I am describing is quite clear in various speeches made by Governor-General Lord Durham to ethnoculturally diverse communities. As recorded in Canada: The Place for the 
reprinted in The Icelandic Canadian during World War II, a period where many Icelanders were strongly committed to Canadian nationhood because of the US occupation of their homeland.

While the patronizing nuances of a statement like Lord Dufferin's probably ring loudly in contemporary ears, similar associations concerning music could support a radically different agenda: arguments of moral superiority. The best-known example is one of the most symbolically significant collections of folk song in Canada, not coincidentally first published within two years of Canadian Confederation and associated with the French literary movement that inspired Québec nationalism during the period. In relation to nationalism, the social context of Gagnon's Chansons populaires du Canada, as thoroughly analyzed by Gordon E. Smith, ${ }^{19}$ is rather widely understood. However, in relation to discourses of morality, Gagnon's interpretation of innate and unselfconscious moral worth in the very style of the music-the modal scales and free rhythmic delivery of folksong which he related to Gregorian chant-is perhaps too often viewed as an odd and isolated idea rather than connected to the broader nineteenth-century context described here. Gagnon's association of modality and moral worth is idiosyncratic in its musical specificity but not in its point of reference. On the other hand, his equation of modality and morality is explicitly not read in class terms. That is, unlike the Ontario choirs Morey describes, moral worth might be signalled by an element of folk music, but moral betterment by means of musical activity was not the issue: "The people sing in the old Gregorian modes, not because they read music that dictates it, but because they obey without the knowledge of an order of superior things coming from God without the knowledge of the relationship between visible and invisible things." 20

The statements I have quoted illustrate that assertions of moral worth could operate either as patronizing means of Othering or as Self-inscribed assertions of moral superiority. The former was more often linked to discourses of class or mapped onto non-Anglo immigrant groups, while the latter was more often linked to discourses of nationalism. Both strategies, of course, deny the

Immigrant (Toronto: J. M. Trout, 1874, microfiche CIHM no. 23908), his comments to British-dominated communities in Ontario most often offer congratulatory remarks on economic development-the fruit-growing potential of Niagara, the oil and industry of Sarnia, the timber and waterways around Parry Sound, for instance. When he spoke in French to a group of francophones in Windsor, however, he lauds and compares "la générosité, l'esprit d'invention, l'élan, la grâce, la délicatesse, la précision du jugement et la finesse artistique des français avec le flegme et le tempérament britanniques," elements united in Canada to govern "le monde moral et le monde physique" (37). He seems to imply a division of French and English responsibility between moral and physical (economic?) authority/well-being. The Icelandic speech a few years later suggests that new immigrant communities on the prairies were aligned with the French in his conceptualization.

19 Among several works exploring these connections are Gordon E. Smith, "Ernest Gagnon (1834 1915): Musician and Pioneer Folksong Scholar" (Ph.D. diss., University of Toronto, 1989), and idem, "The Genesis of Ernest Gagnon's Chansons populaires du Canada," in McGee, Taking a Stand, 221-37.

20 "Le peuple chante dans les vieux modes grégoriens, non pas parce qu'il suit une note écrite qui le veut ainsi ... mais parce qu'il obéit à son insu à un ordre de choses supérieur, venant de Dieu et du rapport qui existe entre les choses visibles et les choses invisibles," Gagnon, Chansons populaires, 326. 
complex range of behaviours and internal contradictions within any social group, as both Chan and Monson, to whom I refer below, are fully aware.

Furthermore, the "burden" of moral worth continues in the twentieth-century: Chan, ${ }^{21}$ for instance, presents many narratives about the energy expended by the Toronto Chinese arts community to be (and be seen as) good citizens. So too do assertions of moral superiority in the larger global context. With regard to African diasporic cultures, Monson has recently written:

If the tendency toward a black-white racial binarism in African diasporic sensibility is structurally reinforced through the continued existence of implicit and explicit ideologies of white supremacy, then one response to this structural condition has been to invert the racial hierarchy by figuring Africa and blackness as morally and spiritually superior to the technological West. If white Western capitalism is exploitative and greedy, then true blackness is spiritual and communitarian; if the West is militaristic and violent, then African tradition is peace loving; if the West is oppressive and stultifying, then blackness is resistant and liberatory. ${ }^{22}$

These statements clearly relate discourses of morality to race. Canadian scholarship could usefully consider a more complex intersection of various fields of tension. The regional differentiation of mappings of class and ethnicity suggest that a high-brow/low-brow divide ${ }^{23}$ emerged differently in various Canadian locales and that different ethnocultural perspectives are essential to understanding this. My examples are most certainly only shards, not substantive evidence, but rather nudges toward questions about the ways in which these mapping and these debates have occurred.

\section{DISCOURSES OF TRADITION AND MODERNITY IN THE INTERWAR PERIOD}

Even though vestiges of morality remain in discourse about both folk and classical music in the early twentieth century, a different field of tension arguably became more prominent in music discourse of the interwar period: modernism and tradition. I think it is accurate to say that most Canadian music historians associate modernism with internationalism, classical composition, the rupture with tonality, and urban locations (especially those of central Canada). Tradition, on the other hand, is associated with the local, folk repertoires, with conservative processes, and culturally specific communities. In this part of the paper, I present some examples of music discourse that disrupt the dichotomies somewhat; both classical and folk music scholars invoked language of the local, national, and international, and struggled be-

21 Margaret Chan, "Chinese-Canadian Festivals: Where Memory and Imagination Converge for Diasporic Chinese Communities in Toronto" (Ph.D. diss., York University, 2001), 175, 208.

22Ingrid Monson, The African Diaspora: A Musical Perspective (New York: Garland, 2000), 13-14.

23 Lawrence Levine, Highbrow/Lowbrow: The Emergence of Cultural Hierarchy in America (Cambridge, Mass.: Harvard University Press, 1988), tends to homogenize regional differences when discussing the construction of class-based cultural divisions in the United States. 
tween the pole of tradition, with its emphasis on re-creation, and modernism, with its commitment to innovation.

In part, this section of my paper responds to a fundamentally important study by historian Ian McKay, ${ }^{24}$ focusing on Nova Scotia, and folklorist Helen Creighton (among others) as constructors of "anti-modernism" in Maritime Canada. ${ }^{25}$ Examining the development of a "folk" industry in that Maritime province, one that related both to the exploitation of folk music and crafts, McKay's work has persuasively indicated how academic emphases and styles of representation could help to shape the identity of a region. Of central importance are his observations that certain segments of society (hearty farmers and fishermen) are validated by such academic emphases while others (e.g., miners, African Canadians) become increasingly "invisible" in the cultural domain. By way of response to McKay, however, I posit that Creighton's issues may have been less idiosyncratic than he suggests. Beyond Nova Scotia and Maritime Canada, the tradition-modernity field of tension was also being negotiated in the interwar period in relation to both classical and folk traditions. Furthermore, Creighton's emphasis on the authenticity of "the folk" was influenced, at least in part, by central Canadian consultants whose perspective on the Maritimes may have been shaped by their own specifically localized position in the great traditions-little traditions field of tension.

By the 1920s and 1930s, both Nova Scotian collector Helen Creighton and Québec folklorist Marius Barbeau had expanded discourses of class beyond the music they studied to matters of academic gate-keeping. Creighton's class-related decisions about songs to include or exclude from publication, however, were arguably most clearly articulated by John D. Robins, the University of Toronto professor who facilitated some of her earlier publications. In one anthology introduction, ${ }^{26}$ Robins commends Creighton for tying her collection to "Professor Child's great canon of balladry," thereby excluding repertoire "whose claim to admission among the lower nobility might have been allowed." That is, Francis James Child is now held up as the arbiter of music that has age as well as (presumed) noble connections, and is thus worthy of legitimation as literature. By such strategies, discourses of class slipped easily into discourses of authenticity and tradition.

This is further illustrated by a twist in the connotations of modality, now recast as a marker, not of moral worth, but of age and authenticity. A noteworthy instance is (another Ontarian) Kenneth Peacock's assessment of the Maritime folk songs he transcribed in the 1930s and 1940s from Creighton's collections: "All the 'best' songs were modal or in a modal style suggestive of medieval music." 27 The validation of old songs relates to the hybridity-pres-

24 Ian McKay, The Quest of the Folk: Antimodernism and Cultural Selection in Twentieth-Century Nova Scotia (Montréal and Kingston: McGill-Queen's University Press, 1994).

25Some years earlier, Richard Handler, in Nationalism and the Politics of Culture in Quebec (Madison, Wisc.: University of Wisconsin Press, 1988), had argued a similar strategy with regard to the commodification of folklore in Québec.

26In Helen Creighton, Songs and Ballads of Nova Scotia (Toronto: Dent, 1932), vii-viii.

27 In Creighton, Maritime Folk Songs (Toronto: The Ryerson Press, 1961), ix. 
ervation field of tension, emphasizing the latter pole, of course. The valuing of preservation is further echoed in his reference to the "encroachments of technical urban culture," a development he regards as "threatening the old traditions of singing," 28 and a fear that was arguably particularly pervasive in the interwar period in relation to the development of public broadcasting. ${ }^{29}$

Barbeau draws the connection between old songs and class slightly differently, within a field of tension between preservation and innovation. In the Introduction to his 1946 collection, Alouette!, he states:

People more or less educated refuse to believe that it would be possible to find beautiful things among the settlers (les habitants), fishermen, farmers, lumbermen, boatmen of the North West, whom they assume to be uncultivated and lacking in taste. They ignore that rustic folk didn't compose the songs that they repeat but simply conserved them in memory; these songs come, for the most part, from the glorious school of French jongleurs from which the origins and poetic resources go back to the beginning of the French language. ${ }^{30}$

While Barbeau clearly understood the variability of performances from one singer to another (studying, for instance, the variants of "Trois Beaux Canards" in a landmark essay of 1947), he did not view the singers themselves as having any agency in these changes, and remained interested in questions of origins and in creating "ideal" versions of song texts in particular (by amalgamating different versions in the interests of narrative completion, for instance). His approach in this regard differed substantially from that of his Maritime colleague Helen Creighton.

While Creighton noted that "it always surprises me how little singers change the words, taking pride in passing them on exactly as they heard them from other singers," it is her surprise that I wish to emphasize. She is prepared to find innovation and open to observing performance variability when it does occur: "a true folk song is not fixed but allows for great flexibility on the part of the performer." 31 If antimodernism is equated with the preservation pole of the preservation-innovation (hybridity) field of tension, Creighton defies simple categorization.

Folklore was further implicated in discourses of modernism as it sought to professionalize as a "modern" academic discipline, partly through publication and commercial distribution. Barbeau allegedly liked to relate that Sir Wilfrid Laurier encouraged him to collect folklore saying (ironically?) "you'll make lots of money." $32 \mathrm{He}$ saw the publication of folk lore as part of the development of the discipline of folklore. By 1918, he had assumed the presidency of the

28 Ibid.

29Extensive debates about the danger that mechanization presented to live performance followed the advent of radio in the late 1920s. These debates cross generic lines and relate to classical music as well as folk music. Tippett, Making Culture, 19, for instance, presents initially negative responses to radio by Ernest Macmillan, Andrew MacPhail, Reginald Stewart, and Leo Smith.

30Marius Barbeau, Alouette! (Montréal: Les Éditions Lumen, 1946), 10.

31 Creighton, Songs and Ballads, vi.

32Lawrence Nowry, Marius Barbeau: Man of Mana (Toronto: NC Press, 1995), 148. 
American Folklore Society and would remain committed to the discipline throughout his career. It is significant that, for Barbeau, the modernist development of professional folklore was associated with the internationalism of disciplinary development, not simply with a nationalist area studies orientation. He saw Canadian folklore as a "bountiful harvest" 33 of "hidden treasures in Canadian soil," 34 and pressured for increased subsidy of the AFS Journal by the provinces of Ontario and Québec by sending masses of Canadian material for publication, more than the journal could publish without additional funding. The mining metaphor, in particular, widely used in this period, ${ }^{35}$ contains a number of significant nuances: that agency lay with the collector, that folk music was seen as a commodity of potential economic value, and that, somehow, the folk material was like natural material of the earth, unlike art or popular music of the day. His efforts to circulate material more widely also included the organization of the Veillées du bon vieux temps concerts and, a decade later, the Folk Song and Handicraft Festivals sponsored by the Canadian Pacific Railway (CPR).

The individual who played the largest role in the organization of these festivals, the CPR publicity agent John Murray Gibbon has, in my view, been underestimated as a forerunner to contemporary Canadian ethnomusicology. Often described as a "popularizer" of folk music, ${ }^{36}$ the Oxford-trained historian has generally been disregarded as a music scholar from the authenticity-driven perspectives of the late twentieth century because he blatantly appropriated folk music for his own purposes. He commissioned piano accompaniments to folk songs and wrote new lyrics representing Canadian themes both for publication and performance within his 1937 radio series, Canadian Mosaic. ${ }^{37} \mathrm{He}$ truly "reinvented" the folk more blatantly than either Creighton or Barbeau, committing completely to the hybridity pole of the hybridity-preservation field of tension.

Gibbon's contributions to studies of Canadian culture, however, are more far-reaching, in my view, than we have yet acknowledged. After becoming publicity manager of the CPR in 1913, he made influential decisions about immigration and settlement, especially in Western Canada. Such decisions were based on detailed knowledge about contemporaneous demographics and the histories of nations and ethnic groups whose members were enticed to Canada. His Canadian Mosaic (both the aforementioned radio series and subsequent book) is effectively an early study of diasporic histories. Commercially motivated, his work, nevertheless, was on occasion overtly anti-racist. ${ }^{38}$

33Letter cited in ibid., 176.

34Ibid., 187.

35McKay, in The Quest for the Folk, 49, notes that both Creighton and Gibbon also used it.

36 See, for example, McKay, The Quest for the Folk, 57-60.

37 The texts for this series, together with photographic and hand-drawn images, including many of musicians and dancers, but not musical transcriptions, were published in a book of the same name: John Murray Gibbon, Canadian Mosaic (Toronto: McLelland and Stewart, 1938).

38On one occasion, he extracted an apology for a demeaning comment by a prominent author after bringing him to see a Polish dance troop at the Winnipeg festival. The writer's penance was to call friends and urge them to see the folklore festival. 
Gibbon placed considerable emphasis on songs composed in Canada (in the introduction to Canadian Folk Songs, for instance), validating what he describes as "modern" folk songs as well as older ones. And yet, his nationalism was not in tension with an internationalism that acknowledged the complex negotiations among dozens of performers (and groups) participating in the CPR festivals. Gibbon understood that music was a site of controversy and identity-making. ${ }^{39}$

What the ethnomusicological precursers of this interwar period struggled with, then, were a number of debates that seem, at the dawning of the twentyfirst century, to be rather current: issues of commodification and commercial exploitation, issues of hybridity and reinvention of the folk. Among the differences, however, is the sense that modernism was linked so strongly to the development of academic disciplines, both by the professionalism associated with them, and by the presumed right of scholars to have complete agency in the use, potential commercial profit, and circulation of the musical material.

In the classical musical world, things were cast somewhat differently. With hindsight, we usually locate the advent of Canadian musical modernism in the 1950 s and 1960s, particularly in association with the policy and institutional developments that emerged from the Massey Report. As Berland has clearly articulated them, the ideologies of Canadian modernism articulated in the Massey Report included:
a dignified antipathy to the dominance of American commercial and popular culture, and the consequent eviction of popular and/or commercially based culture from the terrain of public good; an agreement that artists and artistic works should inhabit an autonomous professional world, accountable only to juries of professional peers who could judge artistic value in its own terms; the belief that national subjects were (or would evolve to become) united by shared cultural values and beliefs, nurtured by the country's arts; the arguably countering belief that art ought to be disengaged and free from local traditions, community standards, commercial markets, politically motivated strategies of representation or other "idiosyncracies"; and the notion that it is artists' responsibility to advance their art. ${ }^{40}$

But the definitions that were clarified by 1951 were still contentious between the Wars. Some play in the fields of tension is evident. While Gibbon's and Barbeau's visions of folklore (usually associated with the "local" pole) were internationalist, various classical music commentators, such as Toronto critic Augustus Bridle, would decry the derivative nature of Canadian music, arguably making composers of both classical and popular music wary of international affiliations and networks. But localness was implicated differently in

39 An instance of this is the description of German participation in the festival of 1929. In rehearsing the grand finale where all participants joined to sing "O Canada" and "God Save the King," the Germans were left out since it was felt that in view of their participation in World War I against Canada they would not wish to sing the Canadian anthem. But the performers protested this omission and asserted their "belonging" (my word) in the final performance.

40Jody Berland, "Nationalism and the Modernist Legacy: Dialogues with Innis," in Capital Culture: A Reader on Modernist Legacies, State Institutions, and the Value(s) of Art, ed. Jody Berland and Shelley Hornstein (Montréal and Kingston: McGill-Queen's University Press, 2000), 17-18. 
debates over modernist style. The struggle that aligned the poles of nationalism and modernism has usually been described accurately as a struggle between generations-age versus youth with an overlay of the tradition-innovation field of tension. Kallmann, ${ }^{41}$ for instance, observed that the younger generation of composers in the 1940s and 1950s frequently asserted that the older generation was not sufficiently "creative." But additionally (though less often acknowledged), discourses about the localness of the older generation emerged during this time. Carruthers' comments on the reception of Percy Grainger in Winnipeg ${ }^{42}$ are instructive here, revealing that, by 1927 , the style of place-specific works such as Country Gardens was described as immature and uninspired. The collaboration of older generation composers, Willan and McMillan, with Barbeau and Gibbon in the CPR festivals of the 1930s, together with their belief that distinctive features would emerge in Canadian music if based on local, traditional (folk) material, was at the crux of the divide.

I suggest that the folkloric work of Creighton, Barbeau and others was not simply anti-modern, but was actually associated with an alternative definition of modernism struggling for position in the musical world. The folklorists and entrepreneurs (and to some extent the older generation of composers) saw modernism as the professionalization of academic study alongside the commercial development and innovative re-creation of local musics. From their perspective, Canadian work was seen as an important contributor within international networks of scholars and artists.

\section{Mosaic EFFECTS IN THE 1960S AND 1970s}

If cultural difference as modifiable, commodifiable, and commercializable was acceptable as a way of negotiating the field of tension between tradition and modernity in the pre-World War II period, ethnomusicologists generally rejected such attitudes by the 1960 s, the decade in which my own professional training began. ${ }^{43}$ Just as the principles of modernism did not become firmly established until the 1950 s, the "mosaic" imagery used as early as $1922^{44}$ to describe the multicultural nature of Canadian society - and current in such 1930 s works as Gibbon's aforementioned study-became naturalized as a basic tenet of Canadian ethnomusicology in the 1960s and 1970s. ${ }^{45}$ In part this

\footnotetext{
41 Helmut Kallmann, "Taking Stock of Canada's Composers: From the 1920s to the Catalogue of Canadian Composers (1952)," in A Celebration of Canada's Arts, 1930-1970, ed. Glen Carruthers and Gordana Lazaravich (Toronto: Canadian Scholars Press, 1996), 24.

42Glen Carruthers, "Percy Grainger in Winnipeg," in Carruthers and Lazaravich, A Celebration of Canada's Arts, 101-8.

43 The 1960s saw the inauguration at the University of Toronto of the first university-level training in ethnomusicology, a discipline that had just been named in the previous decade. But the majority of Canadian ethnomusicologists were still trained in other countries or disciplines such as folklore.

44 The metaphor is usually attributed to Victoria Hayward in Romantic Canada (Toronto: Macmillan, 1922), an account of the Prairie provinces.

45Richard Day's extensive study of the mosaic concept as a fundamental of Canadian identity, "Identity, Diversity and the Mosaic Metaphor: The National Jewel as the Canadian Thing," in Topia: Canadian Journal of Cultural Studies 2 (1998): 42-66, primarily cites critical works from the 1960s forward, thus implicitly supporting my assertion. He notes recent translations of the mosaic image as, for instance, a multi-faceted prism. He argues that the mosaic itself embodied a tension: namely, how
} 
may have happened as the discourse of "immigrants" gave way to the discourse of "ethnicity," as Klymasz ${ }^{46}$ has observed. It is, of course, not surprising that this shift was congruent with the development of policies that are now described as official multiculturalism, or with the rapid diversification of Ontario in the post-war period. In part, it might reflect methodological directions in US ethnomusicology, including an emphasis on more extended field work, and models such as Merriams's tripartite approach to studying musical concepts, behaviour, and sound within a tightly framed concept of discrete cultures, ${ }^{47}$ a concept that often assumed homogeneity within the cultural frame.

At any rate, vis-à-vis the field of tension between the local and the global/ international/transnational/diasporic, an extensive subset of our work of the 1970 s and 1980s tended to focus on the local. Vis-à-vis the homogeneityhybridity dialectic, however, we seemed to be more ambivalent. In the Canadian Folk Music Journal or the Mercury series reports of the National Museums of Canada, the music cultures of specific places come alive: the indigenous communities of Teslin, ${ }^{48}$ Pelly Bay, ${ }^{49}$ or Cumberland Peninsula, ${ }^{50}$ the Finnish settlement of Sointula, B.C., ${ }^{51}$ or the Ukrainians of Waterford, Ontario, ${ }^{52}$ for instance. Regional distinctions between repertoires and styles were articulated. ${ }^{53}$ Around the same time, a number of historical musicology colleagues were also writing about specific cities: music in Halifax and Windsor, ${ }^{54}$ Ottawa, ${ }^{55}$ Québec, ${ }^{56}$ Victoria, ${ }^{57}$ or Edmonton, ${ }^{58}$ for instance. While the ethno-

to yield a national culture from its diverse components. He also questions our uncritical assumptions that Canada is more polyethnic than most modern nations.

46Robert Klymasz, "From Immigrant to Ethnic Folklore: A Canadian View of Process and

Transition," Journal of the Folklore Institute 10 (1973): 131-39.

47 Set forth in his important monograph: Alan P. Merriam, The Anthropology of Music (Evanston,

Ill.: Northwestern University Press, 1964).

48 Marie Francoise Guedon, People of Tetlin: Why Are You Singing? (Ottawa: National Museums, 1974). 49Beverley Cavanagh, Music of the Netsilik Eskimo: A Study of Stability and Change (Ottawa: National Museums, 1982).

50Maija Lutz, The Effects of Acculturation on Eskimo Music of Cumberland Peninsula (Ottawa: National Museums, 1978).

51 Bert Feintuch, "Sointula, British Columbia: Aspects of a Folk Music Tradition," Canadian Folk Music Society 1 (1973): 24-30.

52Anthony Proracki and Alan Henderson, "Ukrainian-Canadian Folk Music of the Waterford Area," Canadian Folk Music Journal 2 (1974): 19-28.

53See, for instance, Timothy Rogers, "Is There an Alberta Folk Music?" Canadian Folk Music Journal 6 (1978): 23-29; or George Proctor, "Fiddle Music as a Manifestation of Canadian Regionalism," in Regionalism and National Identity, ed. Reginald Berry and James Acheson (Christchurch, New Zealand: Association for Canadian Studies in Australia and New Zealand, 1985), 127-33.

54 Timothy McGee, "Music in Halifax, 1749-1799," The Dalhousie Review 49, no. 3 (1969): 377-87; Frederick Hall, "Musical Life in Windsor: 1875-1901," Les Cahiers canadiens de musique/The Canada Music Book 6 (1973): 11-24; Frederick Hall, "Musical Life in Eighteenth-Century Halifax," Canadian University Music Review, no. 4 (1983): 278-307.

55Elaine Keillor, "Musical Activity in Canada's New Capital City in the 1870s," in Musical Canada: Words and Music Honouring Helmut Kallmann, ed. John Beckwith and Fred Hall (Toronto: University of Toronto Press, 1988), 115-33.

56France Malouin-Gélinas, "La vie musicale à Québec, 1840-1845," Les Cahiers canadiens de musique/The Canada Music Book 7 (1973): 9-22.

57 Dale McIntosh, History of Music in British Columbia, 1850-1950 (Victoria: Sono Nis Press, 1989). 58Wesley Berg, "Music in Edmonton, 1880-1905," Canadian University Music Review, no. 7 
musicology studies looked at ethnically specific communities, the historical studies looked for the multiple roots of "classical" music in urban locales. Paradoxically, the composite picture (which no individual scholar can predict without the aid of hindsight) now tells us that we inadvertently perpetuated a number of demographic stereotypes. Namely, we implied that cities were more oriented toward "high" culture even though the vernacular roots of some of the musics presented were quite oblivious of a high-low cultural divide. Further, the composite of the work implied that small communities were ethnically diverse. ${ }^{59}$ In fact, the very opposite seemed to be happening. Our cities were becoming increasingly diverse, classical music increasingly a small niche within that diversity, while rural areas and smaller communities were arguably more monocultural and less open to plurality. ${ }^{60}$

Consistent with an emphasis on the local, a spate of studies emerged that present individual folk artists. One thinks of Edward Ives's books on Larry Gorman, Joe Scott, and others, ${ }^{61}$ Krassen's and Bégin's work on fiddler Jean Carignan, ${ }^{62}$ and Edith Fowke's presentation of major tradition bearers in Ontario such as O. J. Abbott. ${ }^{63}$ Early issues of the Canadian Folk Music Journal contain articles about the Inuit song-writer Charlie Panagoniak, ${ }^{64}$ Acadian singer Angélina Paradis-Fraser, ${ }^{65}$ and collector Roy McKenzie, ${ }^{66}$ among others. But while individualism and collectivities are often posited as oppositional fields of tension in 2000, much Canadian ethnomusicology of the 1970s and 1980s still regarded individuals as unusually gifted but, nevertheless, "representative" of collectivities. In only a few instances, we began to interrogate contradictions and inconsistencies. Internal differences of opinion and the struggles over whose voice is authoritative within communities were other issues that usually remained hidden at this juncture.

(1986): 141-70.

59 There are, of course, exceptions to these patterns, including ethnically specific studies of classical musicians (for example, Cécile Huot, "Musiciens belges au Québec," Les Cahiers canadiens de musique/The Canada Music Book 8 [1974]: 69-77), or studies of urban vernacular traditions (for example, Paul McIntyre, Black Pentacostal Music in Windsor [Ottawa: National Museums, 1976]).

60The monoculture of rural Canada has been reiterated by Gwynne Dyer who states in "Visible Majorities" that 85 percent of new immigrants are going into our seven biggest cities (Canadian Geographic, January-February 2001, 50). But I am not sure that, with regard to music culture, we know the locations of monoculture and hybrid cultures at this point. The picture is undoubtedly more complex than media representations to date.

61 Edward D. Ives, Larry Gorman, the Man Who Made the Songs (Bloomington: Indiana University Press, 1964); Joe Scott, the Woodsman-Songmaker (Champagne: University of Illinois Press, 1979).

62Miles Krassen, "An Analysis of a Jean Carignan Record," Folklore Forum 7 (1974): 161-67; Carmelle Bégin, La musique traditionnelle pour violon: Jean Carignan (Ottawa: National Museums, 1981).

63Edith Fowke, Traditional Singers and Songs from Ontario (Hatboro, Penn.: Folklore Associates, 1965); Lumbering Songs from the Northern Woods (Austin: University of Texas Press, 1970).

64Lynn Whidden, "Charlie Panagoniak: Eskimo Music in Transition," Canadian Folk Music Journal 9 (1981): 34-42.

65Donald Deschênes, C'était la plus jolie des filles: répertoire des chansons d'Angélina ParadisFraser (Montréal: Éditions Quinze, 1982).

66 Martin Lovelace, "W. Roy Mackenzie as a Collector of Folksong," Canadian Folk Music Journal 5 (1977): 5-11. 
It is now easy to use hindsight to criticize the paradigm of "diversity" that framed much academic study between 1960 and the mid-1980s. As early as 1975, Carpenter ${ }^{67}$ described the mosaic concept as one that reified a Eurocentric mainstream by rendering all "other" cultures marginal. More trenchant have been critics of multiculturalism in the 1990s. Bannerji, for instance, has demonstrated how the discourse of "diversity" and "multiculturalism" was part of a strategem to "manage" immigrant cultures, a strategem that effected the "erasure and occlusion of social relations of power and ruling." 68 Culture, viewed horizontally and abstractly, might be celebrated often in the form of essentialized, immutable forms. But real problems of racism, sexism, and hierarchical citizenship were rendered invisible:

In fact, it is this uncritical, de-materialized, seemingly de-politicized reading of culture through which culture becomes a political tool, an ideology of power which is expressed in racist-sexist or heterosexist differences. One can only conclude from all this that the discourse of diversity, as a complex systemically interpretive language of governing, cannot be read as an innocent pluralism. ${ }^{69}$

Bannerji asks who benefits from the discourse of diversity and concludes that it serves governance rather than the governed. Similarly, I think that much ethnomusicological research of this period (including most of my own) tended to "manage" music cultures by denying the modernity of communities in our midst, by ignoring their commercial aspects (both their successes and their frequent struggles), and by failing to enable more access to major venues and media by the musicians with whom we worked.

But at the same time, there were counter-narratives. On the preservationhybridity continuum there was an increasing number of studies that emphasized hybridity within specific communities or individual repertoires, particularly by the early 1980s. Witmer's study of "White" music among the Blood Indians, ${ }^{70}$ Cavanagh's ${ }^{71}$ and Lutz's ${ }^{72}$ monographs on acculturation in Inuit communities, Klymasz's study of Ukrainian country, ${ }^{73}$ and the Newfoundland popular music project $^{74}$ are indications of this current. Closely allied, but more media-savvy

67Carole Carpenter, "The Ethnicity Factor in Anglo-Canadian Folkloristics," Canadian Ethnic Studies 7, no. 2 (1975): 7-18.

68Himani Bannerji, The Dark Side of the Nation: Essays on Multiculturalism, Nationalism, and Gender (Toronto: Canadian Scholars Press, 2000), 50.

69 Ibid., 37.

70Robert Witmer, “'White' Music among the Blood Indians of Alberta," Canadian Folk Music Journal 2 (1974): 35-39.

71 Cavanagh, Music of the Netsilik.

72Lutz, The Effects of Acculturation.

73 Robert Klymasz, “'Sounds You Never Heard Before': Ukrainian Country Music in Western Canada," Ethnomusicology 16 (1972): 372-80.

74Sheldon Posen and Michael Taft, "The Newfoundland Popular Music Project," Canadian Folk Music Journal 1 (1973): 17-23. This project adopted an exceptionally inclusive framework for defining "popular music" as "all music commercially performed, recorded, or printed-be it a traditional Newfoundland ballad or an operatic performance-which is available to the listening public of Newfoundland" (17). 
are studies of transmission processes: Memorial University-based scholars such as Michael Taft and Neil Rosenberg were among those who played an important role here, studying a variety of media including old-time instrumental music books, LP recordings of Newfoundland music, and private manuscript collections. ${ }^{75}$

During this period, historical musicology in Canada similarly intensified production of biographical and/or analytical studies of individual composers. ${ }^{76}$ These were arguably conceptualized within a "great man" paradigm rather than the "cultural representative" paradigm that framed studies of folk musicians. However, in something like a reversal of the interwar pattern, historical studies (vis-à-vis ethnographies) now seemed more open to positioning Canadian music in an international perspective. It would, however, be another decade before an entire subsection of an anthology would be devoted to "border crossing" between Canada and the US.77

\section{Canadian EThNOMUSicology TOWARd AND PaSt THE MILlenNiUM}

It becomes easy to see that the language of socio-cultural difference favoured by one generation usually has developed in response to the shortcomings (or problematic nuances ascribed to) the previous one. The problem becomes how to identify important social issues without reinscribing the problems surrounding those issues. If discourses of moral worth bolstered a self-righteous, narrowly Christian-centred perspective on cultural difference in the late nineteenth century, were any of the competing discourses of modernism any better? If discourses of authenticity and cultural diversity in the 1970s and 1980s obscured real power relationships, and replaced complex cultural realities with homogeneous accounts of the pieces of the Canadian "mosaic," are more recent emphases on hybridity and metissage less prone to be power neutral?

How can we do more than simply reinvent the fields of tension surrounding musical difference; how can we enable a more radical ethnomusicological praxis that not only facilitates exciting art but understands the relationship of expressive culture to issues of social justice? While there are no easy answers, I suggest two potentially fruitful directions. The first, offered in light of the persistence of "colonial" traces identified earlier in relation to academic work over the course of the past century or so, is to explore post-colonial ideas about research methodology. The second is to examine several contingencies of our Canadianness: what are the particular strengths and weaknesses of a position as a scholars working within this nation's academy.

75See, for example, Michael Taft, "LP Recordings of Traditional Newfoundland Music," in Canadian Folk Music Journal 2 (1974): 45-51; or Neil Rosenberg, "A Preliminary Bibliography of Canadian Old-Time Instrumental Music Books," Canadian Folk Music Journal 8 (1980): 20-22.

76 Among the first in this generation of biographies were Brian Cherney, Harry Somers (Toronto: University of Toronto Press, 1975), and Sheila Eastman and Timothy McGee, Barbara Pentland (Toronto: University of Toronto Press, 1983). Canadian Composer ran regular interviews or features on individual composers during this period.

77 In Timothy McGee, Taking a Stand: Essays in Honour of John Beckwith (Toronto: University of Toronto Press, 1985); essays by Smiley, Temperley, and Keillor comprise a section of "Comparative Studies: Canada and the U.S." 
One useful list of strategies for decolonizing research methodologies is a 25-point plan constructed by Maori scholar Linda Tuhiwai Smith. ${ }^{78}$ While her target audience comprises indigenous researchers and some of her ideas may be specifically germane to indigenous cultural issues, her suggestions may be relevant in that they aim to open up the sort of texts that count as research, to determine the best uses of specific methods, and to make new connections between academic aims and community needs. I am particularly struck by one group of her strategies that relate to the validation of individuals, and another that relates to the potential of research on networks and connections. Both these groups, and the relationality they imply, seem relevant for Canadian ethnomusicology.

One group of Tuhiwai Smith's proposed methodologies validate the texts of personal experience: "claiming," "testimonies," "story telling," "celebrating survival," "remembering." In music, the status of individual stories and oral historical accounts is, of course, complicated by the histories of our subdisciplines. Because historical musicology and indeed popular music studies tend to emphasize the great figures, that is, because they put a lot of emphasis on exceptionality, one might argue that ethnomusicology was forced to compensate. We have tended to overdraw the community, the collective values and structures. Such methodologies, however, could have a particular significance in Canadian studies in view of the fact that we might find a way to complement the enormous impact of the US machinery for making stars in the arts. It would be radical and ground-breaking for Canadian music studies to consider accounts/ memories/claims both by musicians who are recognized and those not recognized as well..$^{79}$ In particular, we need to enable the stories of people who are exceptional in many ways, certainly in terms of their musical skill and their impact on their communities, but are neither what we might call stars, nor simply "representatives" of their culture.

My own oral historical research and that of several graduate students in the course of the Canadian Musical Pathways project provided many instances of why a broader range of musicans' stories might be valuable. We heard from individuals who use music as a survival tool in communities where they may be radically marginalized by their race or ethnicity. We learned, for instance, something about what it is like to be a Caribbean musician in the Maritimes, rather than in the large Afro-Caribbean world of southern Ontario, or how French speakers in Saskatchewan attempt to craft a sense of community through music production even though they live very far from the cultural centres of Québec. We encountered unique story-telling genres relating to music in Canada. Stories of touring in remote areas, for instance, or stories of bizarrely staged "multicultural" performances, are uniquely framed by the geo-political circumstances in this country. We learned a lot about the texture

78Linda Tuhiwai Smith, Decolonizing Methodologies: Research and Indigenous Peoples (Dunedin: University of Otago Press, 1999), 142-62.

79 Although numerous musicians and tradition bearers are represented in the oral histories amassed in Canadian archives, experiences of music in Canadian lives are still minimally represented in publication. 
and values that underpin artistic performances from stories that were painful as well as those that were celebratory. We heard, for instance, stories about the bitter irony of doing Japanese music during the World War II incarceration (because such performances could not be done in the cities where residents lived prior to the War), or the emotional intensity of powwows in Canada's prisons: not just the facts of lives, but the desires and hopes could come to light. Many of the individuals whose stories we recorded could easily be lost in conventional studies of music cultures between the cracks of stardom and cultural formation. These are individuals who need to be made more visible.

A wider range of individual accounts relates to another respect in which Canadian scholarship has differed historically from that of the United States: that is what I call its anti-canonization, its reluctance to use scholarship for star-making. A noteworthy instance of anti-canonization, although one that might not self-identity as "ethnomusicological," is the Canadian Musical Heritage Society, an organization that makes anthologies of early printed Canadian music on demand, using digital technologies that make this flexible approach to anthologizing financially practicable. The Canadian Music Centre operates in a similar fashion. The music on demand model, of course, relates to economic contingencies, but its effect is anti-canonization, and this, I think, makes us open to research styles that scholars elsewhere might not envisage. If we tend to refuse to adopt a single definition of canonic repertoire, how then are canons negotiated-in curricula, on media, or among community members, arts entrepreneurs etc. - in Canada? Might anti-canonization be paralleled by a similar rejection of unitary authoritative readings of musical works and performances.

A second group of Tuhiwai Smith's post-colonial research strategies relate to the creation of a climate for cultural change: "revitalizing," "connecting," "reading," "restoring," "returning," "protecting," "creating." Most of these (with the exception of "protecting," which remains a cultural priority in many Canadian community contexts) necessitate the modification of both a blind devotion to authenticity (usually invoked as a discourse with reference to traditional and also popular cultural forms), as well as the modernist belief in the autonomy of art and of the possibility of aesthetic distance from social realities. In musical terms, they would imply that scholars must be centrally involved with artistic innovation and production, with historical restoration and repatriation in many cases, but also with the troubled issues of appropriation and intellectual property rights. Indeed, these continue to be central issues in contemporary ethnomusicology. But specific Canadian case studies are still relatively rare. In my view, we might usefully study the history and development of projects of self-representation that emanate from specific communities. ${ }^{80}$ Simultaneously, the reciprocity for the opportunity to study such projects would necessitate active involvement with artistic enterprises and the issues that relate to them.

80The development of the Aboriginal Television Network comes to mind as do a myriad of CD-ROM sources available to niche markets. 
Furthermore, the strategy of "connecting" as a research priority implies the possibility of enabling new alliances, often ones which go beyond the local or even the national. Those who research complex intercultural performance events $^{81}$ (festivals are a case in point), where the lines between folk and popular culture are blurred or effaced, are one group in a position to observe the complex synergies as well as the boundary-making and ghettoizing that occurs when connections are forged in specific artistic ways. Those who examine continuities between folklore and popular culture have similarly made significant inroads. ${ }^{82}$

Diasporic studies have already proven particularly productive from a Canadian perspective, ${ }^{83}$ as we begin to unfold music's role in the "intradiasporic stratifications of power." 84 In her writing about the African diaspora, Monson, whose phrase I have just borrowed, acknowledges that the hegemonic position of the United States may be felt in other centres of African-derived music to be a new kind of oppression. I suggest that, because diasporic communities in Canada are partially (though variably) outside the symbolic and economic control of the United States (as to what counts as "authentic," who has access to what sort of recording contract, whose sound and image will dominate our media), we may have a clearer picture of the diasporic stratifications of power. Studies of the (un-African-American) stylistic choices of African Canadian artists by Frances Henry and Neil Rosenberg are among the precursors in this area. ${ }^{85}$ Additionally, because many ethnocultures in Canada, in addition to the British and French, have over a century of continuous history, a growing number of Canadian scholars understand the intradiasporic stratifications of power within our country as well as within larger international diasporas of e.g., Ukrainians, Doukhobors, Icelanders, Chinese, or Lebanese. The relative artistic authority of musicians in different cities or provinces are deeply understood but rarely studied, undoubtedly because we fear polemical accounts in academia. But the ways in which performance events serve to articulate such stratifications of power are becoming a central concern in the international ethnomusicological community, and I reiterate that Canadian scholars have a significant perspective from which to undertake such studies.

Similarly, other dimensions of international relationships await Canadiancentred analysis. One has been alluded to at several points in this paper, and

81 At my own University, significant studies of festivals have been made by Sherry Johnson on women's roles in Ontario fiddle festival circuits, Marcia Ostashewski on identity negotiations at Ukrainian festivals in Western Canada and in Poland, Margaret Chan on Chinese festivals in Toronto, and Heather Sparling on Cape Breton tourism. Publications will be forthcoming.

82Folklorists of the Undisciplined Women Collective, particularly Greenhill, Ristock, and Boyd (see Greenhill and Tye, Undisciplined Women) have offered some excellent models.

83 Again I salute a number of graduate students at York University who have done significant work: Brigido Galvan on Latin American perspectives on modernity, Lenka Lichtenberg on music in the lives of Canadian holocaust survivors, Margaret Chan on generational differences among Toronto Chinese listeners responses to the Yellow River Piano Concerto.

84Monson, The African Diaspora, 5.

85Frances Henry, "Black Music in the Maritimes," Canadian Folk Music Journal 3 (1975): 11-21; Neil Rosenberg, "Ethnicity and Class: Black Country Music in the Maritimes," Journal of Canadian Studies 23, nos. 1-2 (1988): 138-56. 
that is the peculiarly "Canadian" field of tension between Canada and the United States. Here, much of the discourse, at least since the strong anti-US definitions of the Massey Commission in 1951, have centred on commercialism. It is not surprising that popular music studies in Canada have flourished in an unprecedented way in the 1990s, a decade that saw this field of tension extensively re-constructed, both by governmental alliances such as NAFTA, but also by cultural analysts ${ }^{86}$ who have observed the many contradictions between financial and cultural policy, and a growing emphasis on a market ideology as a basis for cultural development. ${ }^{87}$ To date ethnomusicologists have been minimally involved in such debates, although I hasten to add that there have been notable exceptions. ${ }^{88}$ Thus far, we still lack a history of Canadian music in a continental perspective. ${ }^{89}$ Indeed, still minimally available is the fundamental research needed for such a study, research about the movement of specific ethnocultural groups within North America, the adaptation of traditions in Canadian vis-à-vis US locales, and the concomitant invention or adoption of new musical practices.

\section{CONCLUSION}

Colleagues in various other academic and creative subdisciplines of music may well wonder whether the issues presented here are as central or important as I have contended. My response is anecdotal: a phone call just came through about an initiative within the Native-American community to convene parties concerned about the appropriation of traditional musics, an issue made more urgent because of such things as the reach and seemingly uncontrolled nature of the internet or packaged, purchasable "samples" of "aboriginal" soundbytes. Then a student came by my office to discuss how to write about the music of a century-old immigrant group for a publication that has a regional perspective substantially different from his own. The dilemma reminds us that the regionally and temporally different histories of immigration to different parts of this country have often shaped deeply felt views of what representations of community, diaspora, and nation should be. Soon after, my e-mail has a passionate message from a graduate who feels multiculturalism is pretentious and euphemizing, while it continues to stigmatize people by labels such as "visible minority" or even "immigrant." I reflect simultaneously on the fact that another student has just written about a performance by a Canadian fiddle and stepdance ensemble performing in the United States for organizers who did not rehire them because the markers of Canadianness were not obvious enough. By such events, each a matter of passion and intellectual import (and, undoubtedly,

86 Joyce Zemans, Where Is Here? Canadian Cultural Policy in a Globalized World (Toronto: Robarts Centre for Canadian Studies, York University, 1997).

87Mike Gasher, "From Sacred Cows to White Elephants: Cultural Policy Under Siege," in Canadian Cultures and Globalization/Cultures canadiennes et mondialisation, ed. Joy Cohnstaedt and Yves Frenette (Montréal: Association for Canadian Studies), Canadian Issues 19 (1997): 13-30.

88 James Robbins, "What can we learn when they sing, eh? Ethnomusicology in the American State of Canada," in Ethnomusicology in Canada, ed. Robert Witmer (Toronto: Institute for Canadian Music, 1990): 47-56, is an insightful exception to the rule.

${ }^{89} \mathrm{~A}$ number of scholars have made a beginning; see note 77 . 
like-and not like-those that fill the days of dozens of other ethnomusicologists in every part of our country), I am regularly challenged by the very framings of selfhood and otherness that specific places and our nation circumscribe. Perhaps better than abstract theorizing, the anecdotes clarify that ethnomusicologists are deeply implicated and complicit in the ways in which social difference has been cast, historically and currently.

Within the study of music in Canada, I want to change the tone of the utterance, "what's the difference," from a sceptical contour that implies "it does not matter anyway," to a (musical) phrasing that indicates we are engaged in the hard issues relating to questions of difference in Canada. A close look at the fields of tensions inherent in the multiple perspectives at any social location may be one useful tactic in moving beyond a discourse that neutralizes the "rich tapestry" of cultures in Canada to one that enables a better understanding of the role that music does and can play in the power-laden, lived experience of difference. We may learn both to worry and to smile.

\begin{abstract}
In different periods of Canadian cultural history, social difference has been articulated by means of discourses of morality, modernism, or mosaics (among others). Each realm of discourse has negotiated various fields of tension between, for instance, the local and the global, tradition and hybridity, or mediated and live performance. These fields of tension are not easily apparent unless we compare discourses relating to different genres of music and sociomusical spheres. The ways in which Canadian ethnomusicology has been complicit with strategies of "managing difference" become clearer with such analysis. Possible post-colonial strategies for empowering voices of difference are also considered in relation to Canadian studies.
\end{abstract}

